\title{
A Linguagem Utilizada na Evidenciação Contábil: uma Análise de sua Compreensibilidade à Luz da Teoria da Comunicação
}

José Maria Dias Filho

Professor da Universidade Estadual de Feira de Santana - BA

Mestrando em Contabilidade e Controladoria -FEAIUSP

\section{RESUMO}

Este artigo procura discutir até que ponto a linguagem utilizada pela Contabilidade é compreendida pelos usuários das informações contábeis.

A hipótese subjacente é a de que as demonstrações financeiras empregam uma terminologia complexa e pouco acessível à maioria dos usuários. Nesse caso, adota-se a premissa de que elas deixariam de ser utilizadas adequadamente no processo decisório ou seriam tratadas como elemento pouco relevante.

Os referenciais teóricos pesquisados enfatizam que a compreensibilidade das informações geradas pela Contabilidade é um dos requisitos necessários para que ela cumpra bem a sua missão. Por isso, recomenda-se o uso de uma linguagem inteligível, que permita ao usuário assimilar o seu conteúdo.

Da análise efetuada, conclui-se que o usuário médio das informações contábeis realmente não consegue compreender perfeitamente o significado de muitos termos utilizados pela Contabilidade. Diante disso, propõe-se a realização de pesquisas periódicas no sentido de identificar as dificuldades predominantes, para que a linguagem contábil se ajuste à sua capacidade de compreensão.

Além disso, considerando a contribuição que a Teoria Matemática da Comunicação tem oferecido ao desenvolvimento de diversos ramos do conhecimento humano, sugere-se que se apliquem os seus conceitos, com maior intensidade, no processo de avaliação e aperfeiçoamento da comunicação contábil.

Palavras-chave: Informações contábeis; Linguagem contábil; Compreensibilidade; Teoria da Comunicação.
ABSTRACT

This article aims at dicussing to what extent the language used by Accounting is understood by the users of accounting information.

The hypothesis raised is that financial statements employ terminology that is complex and not very accessible to the majority of the users, in which case they would not be taken appropriately or would be treated as having little relevance in the decision making process.

The theory related to the theme emphasizes that the comprehensibility of information generated by Accounting is one of the requisites needed for it to accomplish its mission. Thus, the use of understandable language that allows the user to assimilate the content is recommended.

The conclusion, from the analysis performed, is that the average user of accounting information cannot understand well the meaning of many of the words used by Accounting. In view of that, periodic research is proposed in order to identify the prevailing difficulties, so that the language of Accounting may adjust to its capabilities of comprehension.

Moreover, taking into consideration the contribution that the Theory of Communication developed by Calude E. Shannon has brought to the improvement of many branches of human knowledge, we suggest that it be used as a supporting tool to the evaluation and improvement of accounting communication.

KeyWords: Accounting information; Accounting language; Understandability; Communication Theory. 


\section{INTRODUÇÃO}

Baseado no entendimento de que a função nuclear da Contabilidade é identificar, mensurar e comunicar informações destinadas a facilitar a tomada de decisões econômicas, este artigo tem por objetivo discutir a relação existente entre o tipo de linguagem utilizada na evidenciação das informações contábeis e o nível de percepção de seus usuários acerca da realidade que ela busca transmitir.

Assim, a questão central consiste em verificar se os códigos lingüísticos atualmente utilizados pela Contabilidade são bem compreendidos pelos usuários, tendo em vista ser esta uma condição básica para que haja um bom aproveitamento das informações no processo decisório. Nesse sentido, busca-se identificar os possíveis "ruídos" que afetam a transmissão da informação contábil e demonstrar que esse processo pode ser melhorado utilizando os conceitos da Teoria da Comunicação.

Para tanto, adotamos a premissa de que o primeiro passo para o aprimoramento da comunicação contábil consiste em desenvolver metodologias adequadas para avaliar a sua compreensibilidade.

\section{JUSTIFICATIVAS E METODOLOGIA}

A análise de alguns trabalhos apresentados em congressos, e resultados de pesquisas, sugerem que a Contabilidade não está conseguindo atingir um nível de comunicação satisfatório com os seus usuários. $A$ linguagem utilizada na elaboração dos demonstrativos contábeis é apontada por muitos como uma das prováveis causas. Em geral, considera-se que a Contabilidade precisa desmistificar a sua linguagem para simplificar o processo de comunicação da empresa com os acionistas, empregados, credores, investidores e outros agentes igualmente interessados nas informações contábeis. IJIRI (1980:60), por exemplo, enfatiza esse aspecto afirmando que, embora conceitos complexos possam indicar progresso científico, não são necessariamente importantes na arte da administração. O referido autor alerta que, em algumas áreas, a virtude da simplicidade pode ser muito mais relevante e acrescenta que talvez a Contabilidade deva ser uma dessas áreas por representar "a linguagem dos negócios que é usada por muita gente".

Em contrapartida, observa-se que, embora a Teoria da Comunicação tenha sido explorada com muito êxito em diversos ramos do conhecimento, como na Psicologia experimental, Matemática, Lingüística e Biofísica, na Contabilidade ela ainda não tem sido utilizada com a intensidade necessária para elevar a eficácia do seu sistema de informações.

O problema em discussão aparenta ser tão relevante que até a Estrutura Conceitual Básica da Contabilidade aprovada pelo IBRACON - Instituto Brasileiro dos Contadores, em 1986, adverte que falhas de comunicação e evidenciação decorrentes de problemas de linguagem inadequada estão entre os fatores que podem explicar uma eventual queda no grau de utilização das demonstrações contábeis. De fato, estudiosos, como MARTINS (1992:64-69), alertam que uma maior aproximação da Contabilidade com os seus usuários é algo que ainda está a depender de mais pesquisas voltadas para identificar o tipo de evidenciação contábil que eles efetivamente desejam.

Contudo, cabe esclarecer que, nos limites deste trabalho, não se pretende definir uma maneira ideal de comunicar a informação contábil para cada tipo de usuário específico, mas, apenas, tratar de aspectos teóricos que visem à melhoria contínua do processo de comunicação, em termos gerais. 0 pressuposto aqui adotado é o de que a Contabilidade consegue cumprir os seus objetivos fornecendo um conjunto básico de informações para usuários diversificados. Portanto, qualquer referência à necessidade de se corrigirem falhas de comunicação na apresentação das informações contábeis terá sempre como foco o conjunto dos usuários e nunca categorias isoladas.

Além disso, admitindo-se que a inteligibilidade da informação depende também das características do usuário, toda a abordagem ficará vinculada à premissa de que ele possui alguma experiência suficiente para compreender o conteúdo de demonstrativos contábeis. Essa postura apóia-se na opinião do FASB - Financial Accounting Standards Board, segundo a qual, embora esforços devam ser empreendidos para aumentar a compreensibilidade das informações contábeis, elas "devem ser compreensíveis aos que possuem uma noção razoável dos negócios e das atividades econômicas e se disponham a estudá-las com certa diligência". IUDICIBUS (1997:111) reforça muito bem essa tese afirmando que os relatórios contábeis não são capítulos de novelas empresariais que qualquer 
pessoa mobralizada possa entender, mas o resumo de um processo, de uma "forma de pensar" da Contabilidade.

\section{O PROBLEMA DA EVIDENCIAÇÃO - REFERENCIAL TEÓRICO 1}

Sempre que se discute a utilidade da informação contábil, o termo evidenciação permeia as principais reflexões, pois ele se identifica com os próprios objetivos da contabilidade, caracterizando-se como o meio pelo qual ela deve cumprir a sua missão, isto é, comunicar aos seus usuários informações relevantes para orientar decisões.

Segundo Most (1977), as fronteiras da evidenciação se estendem além das demonstrações contábeis, mas esse mesmo autor ressalta que, na visão tradicional, ela ainda está associada à idéia de "relatórios financeiros" voltados para suportar decisões de usuários externos. O certo é que os limites da evidenciação devem ser determinados em função dos interesses e características dos usuários, considerando-se sempre os conceitos de materialidade e relevância.

Em geral, os autores estão alinhados no sentido de que a evidenciação precisa ser "justa, adequada e plena", para permitir uma compreensão satisfatória de todos os elementos contábeis que possam influenciar as decisões. Afinal, se a Contabilidade for considerada como um fim em si mesma, isto é, desvinculada das necessidades do usuário, torna-se um instrumento estéril, sem qualquer serventia.

OFASB trata o problema da evidenciação em duas dimensões básicas:

a) "full disclosure" versus SAR ( Summary Annual Report);

b) "off-balance-sheet"

No que se refere ao "full-disclosure", a premissa fundamental é a de que todos os eventos significativos que, potencialmente, influenciem o julgamento do usuário deverão ser divulgados nas demonstrações contábeis. Alguns especialistas têm questionado se a divulgação em volume tão abrangente e detalhado pode ser absorvida.

Em contraposição, o Summary Annual Report ( SAR) está apoiado na idéia de que as informações contábeis podem ser apresentadas de modo mais resumido para a maioria dos usuários, desde que eles não precisem de informações tão complexas e detalhadas quanto as exigidas pela SEC- Securities and Exchange Commission.

Pesquisas realizadas nos Estados Unidos vêm indicando que a média dos usuários tem pouco interesse em informações mais abrangentes, sendo que outros estudos até revelaram que tais informações não chegaram a contribuir para evitar desastres financeiros de determinadas companhias em períodos subsequentes à evidenciação.

Por último, registre-se que o "Off-Balance-Sheet" tem por fundamento contemplar operações contratadas porém não contabilizadas, a exemplo de contratos futuros, derivativos etc. A posição do FASB é a de que essas operações devem ser evidenciadas, independentemente de registro contábil, por considerar que a sua omissão poderia prejudicar as decisões dos usuários da informação. Aliás, esse é um problema que se verifica também no Brasil, especialmente no que se refere à forma de evidenciação dos derivativos.

Por sua vez, o IASC - International Accounting Standards Committee, através das Normas Internacionais de Contabilidade, estabelece que toda informação relevante deve ser divulgada, a fim de que as demonstrações contábeis sejam claras e compreensíveis. O referido órgão explica que os usuários não podem fazer juízos confiáveis na ausência desse atributo qualitativo e adverte que, muitas vezes, a informação deve ultrapassar o mínimo necessário para satisfazer os requisitos da legislação local ou de autoridades reguladoras.

No Brasil, considera-se que o nível de evidenciação vem evoluindo gradativamente, sobretudo no campo das companhias abertas, em função de contribuições da CVM - Comissão de Valores Mobiliários, que tem empreendido esforços para melhorar o poder informativo das demonstrações contábeis. Entretanto, por questão cultural ou influências das legislações tributária e societária, boa parte dos profissionais adere de forma extremada ao conteúdo de tais legislações, deixando de produzir informações contábeis com maior potencial de evidenciação quando não encontram nelas orientações detalhadas. Sobre esse problema, Hendriksen (1992) explica que não se pode esperar de uma lei detalhes técnicos minuciosos e alerta que isso também não seria desejável para a qualidade da informação. Segundo esse autor, bastariam diretrizes gerais que permitissem explorar os recursos oferecidos pela teoria contábil. Nesses termos, a Lei $6.404 / 76$ ainda é considerada pela maioria dos autores como 
um passo muito importante rumo à evolução do nível de evidenciação no Brasil, muito embora se reconheça que ela peca gravemente no tocante à terminologia contábil. O projeto de reformulação proposto pela Comissão Consultiva da CVM introduz correções reclamadas pelos usuários e sugeridas pelo meio acadêmico.

Quanto às formas de evidenciação, a literatura corrente demonstra que elas podem variar, desde que se preserve a missão de comunicar informações de maneira clara e ordenada. Dentre os instrumentos mais utilizados na divulgação, destacam-se os demonstrativos contábeis propriamente ditos, as notas explicativas, quadros suplementares, o parecer dos auditores independentes e os relatórios da administração.

Em relação à linguagem utilizada, objeto central deste trabalho, a maioria dos autores salienta que ela deve comunicar com fidelidade os fenômenos que busca representar. MARTINS (1998:24), por exemplo, refere-se ao problema terminológico usando os seguintes termos: "desde que duas pessoas resolvam comunicar-se, é absolutamente necessário que passem a dar aos objetos, conceitos e idéias o mesmo nome, sob pena de, no mínimo, reduzir-se o nível de entendimento". O referido autor completa afirmando: "O que comumente se denomina de mero problema de terminologia, talvez fosse melhor tratado como magno problema de terminologia."

Sobre esse mesmo assunto, a ONU - Organização das Nações Unidas, através de um grupo de trabalho de especialistas em padrões internacionais de Contabilidade, considerou que a complexidade dos negócios não pode ser utilizada como pretexto para a apresentação de informações pouco inteligíveis. Em seus relatórios, o referido grupo destacou, por exemplo, que a forma de apresentação, a terminologia adotada, os conceitos e hipóteses estabelecidos devem ser expressos de maneira não ambígua, e suficientemente explicitados, para que a informação seja compreendida com garantia.

Mesmo considerando que o usuário deve possuir algum conhecimento prévio para facilitar a compreensão da informação contábil, especialistas em comunicação defendem que o contexto ambiental e algumas características pessoais são variáveis que devem ser consideradas no processo de evidenciação.

Por isso, sem desmerecer a contribuição que os mais antigos ofereceram à divulgação do conhecimento contábil, cabe questionar se determinadas expressões como rédito, azienda e outras congêneres seriam assimiláveis pelo atual público usuário. Extremos à parte, talvez ainda se utilizem muitos termos que teriam melhor ressonância em ambientes dedicados a reverenciar o passado.

Desse breve referencial teórico, observa-se que pelo menos três questões fundamentais ligadas à evidenciação têm sido discutidas, historicamente: os destinatários da informação, o conteúdo adequado, e as formas de evidenciá-la, assuntos que serão tratados no presente artigo, sob o aspecto da linguagem.

\section{A TEORIA DA COMUNICAÇÃO E A LINGUAGEM CONTÁBIL - REF.TEÓRICO 2}

IUDÍCIBUS (1987:24) considera que a abordagem da Teoria da Comunicação parece ser uma base mais profícua para a Contabilidade e acrescenta que o processo de comunicação contábil, sob essa ótica, leva em conta a habilidade que os usuários apresentam para interpretar a informação adequadamente.

CARVALHO (1991:20-25) refere-se à importância da comunicação contábil, destacando que, no século $X X I$, o Contador será, por excelência, o comunicador da vida empresarial e acrescenta que a vida desse profissional será cada vez mais dedicada ao aperfeiçoamento da comunicação.

Referindo-se à relação existente entre a Contabilidade e a Teoria da Comunicação, Smith \& Smith (1971:352-361) explicam que os princípios dessa teoria podem ser utilizados para avaliar se a Contabilidade está cumprindo adequadamente a função de comunicar as "informações financeiras". No mesmo trabalho, os referidos autores salientam que se essa função não for bem realizada, os demonstrativos contábeis tornam-se inúteis.

Laudie (1987:579-604) refere-se à Contabilidade como um processo de comunicação bidirecional e interpessoal e acentua que o estudo sistemático dos usuários da mensagem contábil implica questionar o significado do que está sendo comunicado. Esse mesmo autor adverte que a linguagem é uma maneira de se expressar o mundo real e, como tal, requer ajustes continuados em função dos agentes que participam do processo. Ele acrescenta que isso tem profundas implicações na maneira como se devem 
conduzir as pesquisas no campo da Teoria contábil e na forma de se entender o papel que a Contabilidade desenvolve no processo econômico.

A percepção da Contabilidade como uma linguagem é enfatizada também por muitos outros autores. Horngren (1974), por exemplo, observa que "a Contabilidade é uma linguagem com um vocabulário especial, direcionado a transmitir a história financeira das organizações".

Nessa mesma linha de raciocínio, Mills (1990:2135) considera que a Contabilidade tem uma certa dependência de terminologia especializada, a qual normalmente está vinculada a determinado contexto histórico. Brandel (1979), citado por Mills, adverte que o uso desse tipo de vocabulário deve ser precedido de alguns questionamentos, tais como:

"Where do they come from? How do they come down to us? Are they likely to mislead us?

Anthony \& Reece (1975) destacam que a Contabilidade se assemelha a uma língua em que algumas de suas regras são definitivas, enquanto outras não, e explicam que, assim como existem diferentes opiniões entre os gramáticos a respeito de sintaxe e semântica, também os contadores possuem diferentes opiniões sobre a melhor maneira de se registrarem e comunicarem os eventos econômicos.

Ijiri (1975:14), por sua vez, afirma que a Contabilidade, como linguagem dos negócios, deve seguir certas regras e adaptar-se às mudanças ambientais para não correr o risco de ser mal interpretada:

"As the language of business, accounting has many things in common with other languages. (...) To express an event in accounting or in English, we must follow certain rules. Without following certain rules diligently, not only does one run the risk of being misunderstood, but also risks a penalty for misrepresentation, lying or perjury. (...) At the same time, language has to be flexible enough to adapt to a changing environment."

BEDFORD \& BELADOUNI (1962:650/9) consideram que a Teoria Matemática da Comunicação, desenvolvida por Shanon, pode funcionar como um instrumental de grande valor na realização de pesquisas contábeis, não apenas em função de sua base matemática, mas principalmente pela estrutura conceitual, a partir da qual a informação é abordada como um fenômeno redutor de incertezas e dependente do estado mental do receptor.
EPSTEIN (1988:64), reportando-se a essa Teoria, afirma que "a informação subjetiva de uma seqüência de signos depende do estado de espírito do receptor, das circunstâncias, do seu comando da linguagem e da sua situação quando recebe a mensagem".

Nessa mesma linha de raciocínio, HENDRIKSEN (1999:524) ressalta que "devido às limitações de atenção e da capacidade de compreensão dos seres humanos, os dados contábeis precisam ser resumidos para terem significado e serem úteis". Esse mesmo autor adverte que "títulos e descrições apropriados dos itens contidos nas demonstrações podem ser esclarecedores para o leitor, mas termos obscuros só podem levar à confusão ou incompreensão".

\section{O PROBLEMA DA COMPREENSIBILIDADE: UM DIAGNÓSTICO}

Definindo os atributos qualitativos da informação contábil, o FASB, através do Statement of Financial Accounting Concepts $n^{\circ}$. 2, editado em 1980, classificou a compreensibilidade como uma das características que ajudam o usuário a assimilar o significado das informações. Oreferido órgão destaca a importância desse atributo, usando os seguintes termos:

"The benefits of information may be increased by making it more understandable and, hence, useful to a wider circle of users".

Apresentando as conclusões de uma pesquisa realizada sobre a evidenciação de informações em companhias abertas, GUAGLIARDI (1987) destaca que a compreensibilidade das informações deve ser meta constante a ser atingida pela administração, contadores e auditores, para que a Contabilidade cumpra o seu objetivo de suprir estratos de usuários com informações claras e justas.

Procurando verificar se essa meta está sendo atingida, SILVA (1995) realizou uma pesquisa junto a administradores de empresas situadas na região metropolitana de São Paulo. O autor explica sua opção por esse segmento de usuários ao considerar que ele constitui uma amostra representativa de outros agentes interessados na informação contábil, tais como fornecedores, clientes, pequenos investidores, empregados etc.

Considerando as características da população pesquisada, imaginou-se que os problemas de 
comunicação eventualmente detectados no referido segmento seriam extensivos ao conjunto de usuários. Outro dado importante para a avaliação dos resultados apurados é que $90,8 \%$ da população pesquisada possuía formação superior, sendo que $62,6 \%$ eram oriundos dos cursos de Economia, Administração e Contabilidade. Portanto, considerou-se que tais usuários possuíam conhecimentos razoáveis para permitir-Ihes uma boa compreensão do conteúdo de demonstrativos contábeis. Conforme salienta o autor, a preocupação central da pesquisa foi observar se o código lingüístico utilizado pela Contabilidade estava sendo entendido pelo usuário das informações contábeis.

As conclusões obtidas indicaram que a Contabilidade emprega palavras que são desconhecidas para os seus usuários, provocando uma subutilização dos demonstrativos contábeis. Verificou-se, por exemplo, que a maioria dos pesquisados que têm opinião formada sobre o grau de entendimento das informações contidas no Balanço Patrimonial não consegue compreendê-las por completo. A principal sugestão oferecida pelo público pesquisado no sentido de melhorar a apresentação desse demonstrativo foi a de que a Contabilidade deveria adotar uma linguagem mais simples.

Quanto à terminologia, observou-se, por exemplo, que "mais da metade dos pesquisados não consegue entender perfeitamente o significado da conta Banco Conta Movimento". Em relação aos que não possuem formação contábil, a situação é bem pior. Para eles, o termo equivalência patrimonia/se apresenta como algo quase que totalmente estranho. De igual forma, mais da metade dos pesquisados não compreendia adequadamente o significado da conta provisão para devedores duvidosos. Aliás, constatou-se que o termo provisão sequer foi compreendido pelos usuários em geral, o que indica ser aconselhável substituí-lo por outro capaz de expressar melhor a idéia que se deseja comunicar, conforme sugeriu a pesquisa. $O$ mesmo foi constatado em relação aos termos Reserva de Capitale Saldo Credor da Correção Monetária, haja vista que a maioria dos usuários revelou desconhecer o significado preciso de ambos.

Em sentido amplo, percebeu-se que os usuários das informações contábeis "possuem dificuldades para captar corretamente as mensagens emitidas pela Contabilidade." Comentando alguns desses resultados, o autor da pesquisa adverte que "seria cômodo para os contadores justificar esse resultado, afirmando que os usuários não estão preparados para entender as mensagens emitidas pela Contabilidade". Porém, como a maioria dos pesquisados afirmou que a Contabilidade faz uso de expressões desconhecidas, conclui-se que realmente é necessário repensar a forma de comunicação, utilizando-se, talvez, palavras substitutas com maior poder de expressão.

Outro aspecto a ser considerado no processo de evidenciação, pelo menos em relação às companhias abertas, diz respeito ao parecer dos auditores independentes, o qual tem por finalidade oferecer ao usuário uma imagem do grau de aderência das informações contábeis aos princípios de Contabilidade. Sema pretensão de discutir até que ponto ele transmite segurança ao usuário, haja vista que essa abordagem exigiria a análise de outros fatores além da compreensibilidade, limitamo-nos a questionar se 0 público-alvo estaria apto a entender o seu significado a partir da terminologia utilizada, sem riscos de efetuar interpretações incorretas. É provável que muitas expressões utilizadas no corpo do parecer não se apresentem compreensíveis para o usuário, sobretudo quando se faz referência explícita a procedimentos adotados, tais como circularização, testes de aderência e outros do gênero. Como se vê, trata-se de termos especializados que certamente não integram os referenciais lingüísticos do usuário médio da informação contábil. A título de exemplo, saliente-se que esse fato foi comprovado através de uma investigação efetuada por Pound (1981:45-55), quando se verificou que o nível de escolaridade requerido para uma razoável compreensão dos pareceres de auditoria, em diversos ambientes, não poderia ser inferior ao universitário.

Para VAINI (1992), esse é um problema que deverá ser corrigido no futuro, tendo em vista que ao usuário não importará saber, por exemplo, qual a "extensão do trabalho do auditor; o importante será a sua opinião clara, concisa, objetiva e que transmita aquilo que o público precisa saber de maneira inteligivel". No mesmo trabalho, o referido autor afirma que não faz o mínimo sentido explicar num parecer que os exames foram efetuados de acordo com as normas de auditoria. Ele argumenta que não poderia ser de outra forma e que, além disso, ao público não interessa um detalhe dessa natureza. 
Em relação às notas explicativas, concebidas originalmente para aumentar o poder de evidenciação das demonstrações contábeis, verifica-se que muitas vezes se utilizam de uma terminologia pouco esclarecedora sobre a natureza dos eventos que objetivam retratar. Em alguns casos, assumem uma complexidade tamanha que acabam dificultando a correta interpretação das demonstrações contábeis ou então descambam para o extremo de expressar fatos absolutamente óbvios, como, por exemplo, declarar que o Patrimônio Líquido resulta da diferença entre ativos e exigibilidades. Hendriksen alerta que a crescente complexidade das empresas poderá estimular o uso abusivo de notas explicativas, resultando em prejuízos ao entendimento de seu conteúdo.

Nos Estados Unidos, diversas pesquisas têm sido realizadas no sentido de avaliar a compreensibilidade dos demonstrativos contábeis, especialmente no que se refere às notas explicativas (footnotes) e às Management's Discussion and Analysis (MD\&A), espécie de relatório cuja apresentação é exigida pela Securities and Exchange Commission (SEC) para discutir tendências de liquidez, recursos de capital, geração de resultados operacionais e outros assuntos correlatos. Gibson e Schroeder (1990:78-87) afirmam que cada estudo realizado se encarrega de demonstrar que o nível de entendimento manifestado pelos usuários a respeito das notas explicativas tem sido muito baixo. Como exemplo, os autores citam uma investigação que realizaram para avaliar as características da linguagem utilizada na elaboração de Notas Explicativas incorporadas às demonstrações contábeis dos maiores bancos internacionais situados em nove países de língua inglesa. A fundamentação da pesquisa indicava que a complexidade da linguagem contábil e a conseqüente redução da compreensibilidade dos "relatórios financeiros" poderiam exercer efeitos adversos sobre o processo de análise e interpretação efetuado por credores, investidores e depositantes. Na prática, considerouse que o comportamento desses agentes poderia ser influenciado pelas características da linguagem contábil, na medida em que as informações não se prestassem à redução de incertezas. Os resultados comprovarama existência de problemas relacionados à compreensão das informações contábeis, em função da linguagem utilizada pelas notas explicativas e também em razão de terminologias adotadas em diferentes países. Finalmente, concluiu-se que as demonstrações contábeis não estavam contribuindo para a otimização dos resultados das instituições em questão. As variáveis utilizadas para mensurar o grau de compreensibilidade das informações foram o comprimento das palavras e das sentenças e o uso da voz passiva.

Em outros estudos empreendidos pelos mesmos autores, observou-se que cerca de $60 \%$ dos investidores profissionais, embora já familiarizados com a complexa terminologia dos demonstrativos contábeis, consideraram que as informações seriam melhoradas se as notas explicativas fossem redigidas numa linguagem mais compreensível e livre de jargões técnicos. Verificou-se também que o uso da voz passiva, a extensão das palavras e das sentenças são os fatores que mais afetam a compreensibilidade. Sobre o mesmo assunto, Lesikar e Lions (1986:21) explicam que uma narrativa com uso predominante da voz passiva é menos incisiva, mais árida, mais prolixa e menos interessante. Já o comprimento da palavra e das sentenças, segundo eles, tende a influenciar a velocidade de reconhecimento do leitor. Os referidos autores explicam também que existe uma forte correlação entre o comprimento das palavras utilizadas na estrutura das notas explicativas e o grau de dificuldade de compreendê-las.

Quanto à terminologia propriamente dita, Golube Kueppers (1983) afirmam que normalmente as notas são redigidas num estilo e vocabulário que somente contadores e advogados podem compreender. Avaliando a compreensibilidade das informações contábeis em função de palavras, sílabas e sentenças extraídas de 1974 "relatórios financeiros" publicados por companhias estabelecidas nos Estados Unidos, Worthington (1978:27-32) chegou às seguintes conclusões:

"Financial footnotes are understood only by an audience considerably more sophisticated in reading ability than average investors."

Para demonstrar a importância que o problema da linguagem exerce no processo de comunicação das informações contábeis, pesquisadores, em diversos países, investigam até que ponto um maior ou menor grau de compreensibilidade pode interferir no desempenho da empresa. Smith e Taffler (1992:75-90), por exemplo, constataram que existe relação entre níveis de compreensibilidade e desempenho financeiro, notadamente no que se refere às variáveis lucro, 
liquidez e riscos. Jones (1988:297-305), por sua vez, observou uma significativa relação associada ao retorno sobre o capital empregado, ao volume de vendas e também alguns reflexos sobre a imagem da empresa. Uma forte relação entre a compreensibilidade das informações contábeis e o retorno sobre o Patrimônio Líquido também foi identificada por Baker e Kare (1992:1-4), mas no mesmo estudo ficou comprovado que essa relação não se verifica com a mesma intensidade no tocante ao comportamento das ações ordinárias e do lucro líquido obtido com vendas.

Como se observa, os estudos acima referidos revelaram existir vínculos entre a compreensibilidade da informação contábil e o desempenho econômicofinanceiro da entidade. Alguns autores chegaram a sugerir a realização de pesquisas adicionais para verificar o impacto que o fator compreensibilidade pode exercer sobre o comportamento do mercado de ações, por exemplo. Outros julgam relevante examinar até os aspectos éticos associados a estratégias de comunicação da informação contábil, envolvendo análise de estilos e outros elementos que poderiam influenciar a compreensibilidade.

Efetuando-se uma revisão mais aprofundada sobre a maioria dos estudos até agora desenvolvidos coma finalidade de investigar o problema da compreensibilidade das informações contábeis, observa-se que as características da linguagem vêm sendo freqüentemente apontadas como um forte obstáculo ao entendimento do conteúdo das demonstrações contábeis. Em geral, conclui-se que, para o usuário médio, a compreensão dessas demonstrações se apresenta como algo inacessível ou, pelo menos, muito difícil. Muitos autores consideram que, independentemente de se tratar de um estilo de comunicação adotado pela Contabilidade, esse problema constitui um desafio para aqueles que reconhecem que a relevância das informações contábeis depende em muito da forma como são comunicadas. Emambientes onde elas são largamente utilizadas para suportar decisões de investimentos, conforme salientado por Gibson (1986:67-70), a questão assume maior importância e, por isso, vem provocando discussões com vistas à identificação de caminhos que possibilitem uma melhor sintonia entre a Contabilidade e os usuários.

Por considerar que a compreensão das informações contábeis demanda alto nível de conhecimento técnico, conforme revelações de pesquisas, alguns estudiosos propõem que a empresa divulgue dois conjuntos de demonstrativos contábeis em cada período: um obedeceria aos moldes convencionais e o outro adotaria uma linguagem mais simplificada e compreensível. Mas há também quem defenda que os jargões técnicos deveriam ser reduzidos ou eliminados para viabilizar uma melhor compreensão da informação contábil, isso em qualquer circunstância. Já outras correntes consideram que a melhor solução seria testar a compreensibilidade das informações contábeis, periodicamente, entre os diversos grupos de usuários e efetuar os ajustes que se manifestassem necessários, opinião que se afina com as premissas adotadas neste artigo.

Comprovada a existência de problemas no processo da comunicação contábil e identificadas as respectivas causas, é compreensível que realmente se vislumbrem múltiplas soluções. Porém, sem qualquer pretensão de resolver o impasse, consideramos que essa questão merece ser tratada de forma mais abrangente, à luz de uma teoria que possa oferecer respostas em diferentes circunstâncias.

\section{A TEORIA DA COMUNICAÇÃO: UM CAMINHO PARA O AJUSTE DA LINGUAGEM}

Destacando a larga aplicação da Teoria Matemática da Comunicação no desenvolvimento de diversos ramos do conhecimento humano, Epstein (1988:6) questiona como uma teoria que fora desenvolvida para a finalidade específica de solucionar problemas técnicos de comunicação extravasou estes limites e adquiriu importância considerável em outras áreas como psicolinguística, economia, desenho industrial, psicologia, biologia, pedagogia, etc.

Diante disso, cabe questionar também por que a Contabilidade, sendo essencialmente um processo de comunicação, não vem explorando com maior amplitude os recursos oferecidos pela referida

teoria para melhorar a sua comunicação com o usuário.

Pode-se argumentar que a identificação dos problemas de comunicação existentes na área contábil já significa um grande passo para se obter uma maior aproximação entre a Contabilidade e seus usuários, o que é verdadeiro, mas cremos que a concretização desse objetivo ainda está a depender do manuseio de ferramentas mais eficazes. Alguns autores consideram 
que a Teoria da Comunicação pode ser um desses instrumentos, mesmo sabendo que ela foi concebida para resolver, prioritariamente, problemas de otimização do custo da transmissão de sinais. Eles se baseiam na experiência de outros ramos do conhecimento humano, como a Psicologia, que utiliza os princípios dessa Teoria para avaliar textos lingüísticos, tanto no que se refere à informação objetiva, calculada exclusivamente a partir de medidas efetuadas sobre o texto, quanto à subjetiva, computada em função do desempenho de determinados sujeitos ou classes de sujeitos frente a textos, conforme descrito por Epstein (1988:64).

Outros especialistas em comunicação destacam a importância dessa teoria afirmando que ela apresenta a vantagem de permitir a fixação de textos para diferenciar sujeitos e vice-versa.

Portanto, há de se admitir que a Contabilidade deveria utilizar ou, pelo menos, testar esses conceitos com maior intensidade para obter melhores resultados nas tentativas de adequar a sua linguagem à capacidade de compreensão do usuário. Autores da área contábil que se dedicaram a esse tema, como Bedford e Baladouni (1962:650/9) costumam afirmar que o primeiro passo nessa direção consiste em compreender a contabilidade como um processo de comunicação e perceber como os seus componentes interagem. Segundo eles, isso implica conhecer as relações que se desenvolvem entre diversos elementos, tais como: o contador e os eventos econômicos, o usuário e as demonstrações contábeis, o usuário e os eventos sócio-econômicos, a empresa e o mundo dos eventos econômicos, entre outros fatores que deveriam ser contemplados no modelo de comunicação.

O segundo passo seria identificar um modelo específico de comunicação que pudesse ser adotado pela Contabilidade para maximizar a sua função informativa. Entretanto, como o leque de usuários é muito amplo e distinto no tocante a características e interesses, certamente não seria produtivo empreender um esforço dessa natureza, visto que, em tais circunstâncias, a utilidade de qualquer modelo tenderia a ser muito limitada. Desse modo, é preferível considerar os princípios que fundamentam todos os modelos de comunicação, de uma maneira geral, e tentar aplicá-los aos sistemas de informações contábeis.

Partindo dessa premissa, talvez um bom referencial para a Contabilidade seja o modelo preconizado pelo próprio Shannon, em sua Teoria Matemática da Comunicação, que é constituído dos seguintes elementos: mensagem, emissor, canal, receptor e destinatário. Na verdade, até mesmo alguns modelos mais simplificados podem ser utilizados, desde que contemplem os pilares indispensáveis à caracterização do processo de comunicação: mensagem, emissor e destinatário.

Essa visão sistêmica do processo de comunicação nos ajuda a compreender que o problema da linguagem contábil deve ser considerado de forma contextualizada, partindo do emissor até chegar ao destinatário. Ao receber informações sobre os eventos econômicos, o emissor deve interpretá-las fielmente, selecionar o conteúdo de interesse do usuário e codificá-lo de forma compreensível. Assim, verificase que a qualidade da comunicação depende fundamentalmente da interpretação humana: o emissor, a quem cabe definir o conteúdo e a forma do que será comunicado, e o receptor, que deverá estar apto a decodificar a mensagem. Entre os dois está a linguagem utilizada para transmitir a informação contábil.

É certo que o emissor também está sujeito a problemas de compreensão da linguagem, haja vista que os eventos econômicos precisam ser interpretados e comunicados por meio dos demonstrativos contábeis. Uma eventual limitação nesse ponto não pode ser ignorada, mas identificada e superada no processo de elaboração da mensagem, até porque nenhum argumento poderá convencer o usuário a se satisfazer com informações incompreensíveis ou incompletas. Ao contrário, em qualquer circunstância, as razões pelas quais se busca a informação contábil e a capacidade que o seu destinatário possui para compreendê-la são fatores que devem influenciar a forma e o conteúdo da mensagem.

Os conceitos da Teoria da Comunicação atestam que a eficácia de uma mensagem é medida pela quantidade de informação assimilada e pelo volume de alternativas que ela permite ao usuário descartar. Em essência, informação é redução de incerteza e, nesse sentido, a validade das informações contábeis não pode ser determinada senão medindo o nível de incerteza do usuário entre dois momentos: antes e depois de receber a mensagem. Essa transformação que se espera venha ocorrer está fortemente relacionada à capacidade de compreender o que está 
sendo transmitido. Assim, os demonstrativos contábeis não constituem uma informação com existência própria, mas, apenas, um conjunto de códigos ainda carentes de significado. Em termos científicos, é incorreto pensar que eles contêm um significado intrínseco, pois que esse emana sempre da consciência interpretadora do destinatário. Se o usuário da mensagem não conseguir interpretá-la, não se pode dizer que tenha ocorrido uma comunicação, pois o ato comunicativo depende do conhecimento de um código capaz de unir o transmissor ao receptor, e sem ele a informação torna-se um ruído sem qualquer valor semântico.

IUDICIBUS (1997:113) destaca esse problema com muita lucidez, afirmando que "é importante utilizar, nas demonstrações contábeis, uma terminologia clara e relativamente simplificada". Esse mesmo autor adverte que "termos (e grupos) obscuros como 'resultado pendente', 'pendente' ou mesmo 'resultado de exercícios futuros' devem ser evitados, por não serem precisos".

Discorrendo sobre a função informativa das demonstrações contábeis, Smith e Smith (1971:35261) explicam que a comunicação só se concretiza se o código utilizado pelo emissor estiver ao alcance da compreensão do receptor. Isso significa que, a princípio, qualquer informação é um dado incompleto, até o instante em que o seu destinatário Ihe atribua um significado como produto da observação pessoal e de seus referenciais cognitivos. Por isso, os autores que abordam o problema da comunicação na perspectiva do usuário enfatizam que os sistemas nunca devem ser baseados apenas na ótica dos projetistas, analistas e nem mesmo dos cientistas da informação, principalmente quando se considera que, em regra, eles são concebidos para auxiliar a tomada de decisão dentro de um contexto particular

$\mathrm{Na}$ mesma direção, Bedford definiu as características de uma comunicação perfeita, usando os seguintes termos:

"If a message is produced with hundred per cent fidelity and interpreted by the destination with hundred per cent fidelity, then we can say that there is perfect communication of messages."

Em seguida, esse mesmo autor adverte que raramente as mensagens são codificadas e decodificadas com cem por cento de fidelidade. Obviamente, se as informações contábeis não refletirem com fidelidade os eventos econômicos da empresa, mesmo que o usuário consiga decodificálas integralmente, também não se pode dizer que ocorreu uma comunicação perfeita, já que a realidade deixou de ser representada em plenitude.

Mesmo que a Contabilidade já esteja estruturada sob uma linguagem historicamente organizada, com representações simbólicas bem definidas, é preciso considerar que o seu significado não existe fora do indivíduo. Os processos perceptivos se alteram em função do contexto porque os referenciais utilizados para compreender as informações externas são dinâmicos. Na chamada Era do Conhecimento, será que termos como Ativo, Passivo, Débito e Crédito ainda expressam a mesma realidade que com eles se desejava expressar no século passado? Que significado o Frade Luca Pacioli, em sua época, poderia atribuir aos termos software, security, joint venture ou internet?

Não se pode ignorar que o usuário evoluiue continua sendo a razão de ser da Contabilidade. Por isso, ela deve adaptar-se às suas características e "entender" que o uso de qualquer informação é modelado pelo estilo cognitivo do indivíduo. No passado, as limitações dos sistemas contábeis e da própria linguagem que se utilizava eram mais toleradas porque as necessidades e alternativas disponíveis também eram muito reduzidas. Dados eram armazenados, precariamente, em documentos impressos e acessados num futuro remoto; hoje, pelo contrário, a informação se desloca de um ponto a outro do planeta em fração de segundo, altera comportamentos e se insere no cotidiano das pessoas como um ingrediente imprescindível ao processo decisório. Ela não se configura mais como tijolos que preenchem o enorme vazio do usuário, mas como argila que toma forma em suas mãos.

\section{CONCLUSÕES}

Percorrendo alguns estudos realizados para avaliar a compreensibilidade das informações contábeis, verifica-se que, efetivamente, existe correlação entre o tipo de linguagem que se utiliza na elaboração das demonstrações contábeis e a forma como seus usuários percebem o seu conteúdo. Na maioria dos casos, observou-se que o usuário médio da contabilidade não consegue compreender as informações veiculadas nesses demonstrativos por desconhecer o significado de muitos termos que são 
utilizados na evidenciação dos eventos econômicos. Nessas circunstâncias, os dados contábeis são mal interpretados ou subutilizados, deixando, portanto, de cumprir a finalidade a que se destinam.

No que se refere à Teoria da Comunicação, considera-se que ela pode contribuir para maximizar a função da contabilidade, na medida em que oferece o aparato conceitual básico para se avaliar até que ponto os usuários estão compreendendo as informações contábeis que lhes foram fornecidas. Além disso, ela ajuda a compreender que o processo de comunicação é essencialmente dinâmico, contextualizado numa dimensão psico-social, e, por isso, os códigos lingüísticos devem se amoldar à capacidade de compreensão dos usuários.

Isso não significa dizer, necessariamente, que a Contabilidade deve adequar a sua linguagem às características de cada tipo de usuário, em particular. $\mathrm{Na}$ verdade, o que se propõe neste artigo é que se investiguem as características médias dos usuários em geral e que se identifiquem os elementos mais significativos que merecem ser considerados no processo de comunicação da informação contábil. É certo que os usuários têm necessidades diferenciadas, reagem à informação de modo específico, mas, enquanto se movem no tempo e no espaço, possuem valores e objetivos que podem ser compartilhados. $A$ Contabilidade precisa considerar esses referenciais na relação que estabelece com o usuário de suas informações.

Incorre em equívoco tanto quem pensa que a evolução tecnológica está ameaçando o futuro da Contabilidade como os que alimentam a crença de que ela sozinha vai potencializar a sua utilidade. Pelo contrário, acima de tudo está a inteligência criadora, a vontade do produtor e do usuário da informação. No contexto atual, a tecnologia deve ser utilizada, isto sim, como instrumento de aproximação entre ambos. Hoje, temos melhores condições de ouvir o usuário, identificar suas necessidades e de conhecer a linguagem que ele entende. Não há justificativas, portanto, para permitir que se amplie o hiato entre a Contabilidade e seus usuários. O ponto crítico não é mais a diversidade dos modelos decisórios e muito menos o grau de exigência que eles nos impõem. Na verdade, o que se faz necessário é alterar a visão dos profissionais em relação à natureza dos seus serviços e prepará-los para atender às novas demandas que estão surgindo, as quais de maneira alguma podem ser interpretadas como ameaças, mas como oportunidades que estão a ampliar os próprios horizontes da Contabilidade.

\section{BIBLIOGRAFIA}

AMERICAN ACCOUNTING INSTITUTE OF CERTIFIED PUBLIC ACCOUNTANTS. Statement $n^{\circ}$. 4. New York: AICPA/APB, 1973.

ANTHONY, R. N. \& REECE, J. S. Management accounting: text and cases. Homewood, IL: Irwin, 1975.

BAKER III, H. E. \& KARE, D. D. Relationships between annual report readability and corporate financial performance. Management Research News, n. 4 (1992): 1-4.

BEDFORD, Norton M. \& BALADOUNI, Vahe. A communication theory approach to accounting. Accounting Review (1962): 650-659.

BRANDELL, F. The wheels of commerce (Civilization and Capitalism, $15^{\text {th }}-18^{\text {th }}$ Century). New York: Harper and Row, 1979.
CARVALHO, L. Nelson. Contabilidade \& ecologia: uma exigência que se impõe. Revista Brasileira de Contabilidade. n. 75, p. 20-25, abril/julho 1991.

DOPUCH, Nicholas \& SUNDER, Shyam. Fasb's Statements on objectives and elements of financial accounting: a review. The Accounting Review, p.11, jan. 1980 .

EPSTEIN, Isaac. Teoria da Informação. 2. ed. São Paulo: Ática, 1988.

GIBSON, V. R. The president's letter to stockholders: a new look. Financial Analyses Journal. $n .5$ (1986): 67-70.

GOLUB, S. J. \& KUEPPERS, R. J. Summary Reporting of Financial Information: Moving Toward More Readable Annual Reports (Financial Executives Research Foundation, 1983), Foreword. 
GUAGLIARDI, José Rafael. A Evidenciaçāo de informaçōes em companhias abertas - um estudo exploratorio. Tese de doutoramento apresentada à FEA USP - Săo Paulo - 1987.

HENDRIKSEN, Eldon S. \& BREDA, Michaol F. Van. Tooria da contabiuidade. Trad. de Antônio Zoratto Sanvicente. 5. ed. Săo Paulo: Atlas, 1999.

Accounting theory. 5. ed. Chicago: Irwin, 1999.

HORNGREN, Charles T. Accounting for managoment control. Englewood Cliffs, NJ: Prentice-Hall, 1974.

IJIRI, Y. Theory of accounting measurement. Sarasota, FL: American Accounting Association, 1975.

IPECAFI, IBRACON. Estrutura conceitual básica da contabîidade. Säo Paulo, 1986.

IUDiCiBuS, Sérgio de. Teoria da contabilidade. 5. ed. Săo Paulo: Atlas, 1997.

Teoria da contabilidade. 2. ed. Săo

Paulo: Atlas, 1987.

JONES. A longitudinal study of the readability of the chairman's narrative in the corporate reports of a UK company. Accounting and Business Research. n. 18 (1988): 297-305.

LAUDIE, D. The accounting of interpretations and the interpretation of accounts. Accounting, Organizations and Sociefy (Junho 1987): 579.604.

LESIKAR, R. L. \& LYONS, M. P. Report writing for business (Homewood, Illinois : Irwin, 1986), p. 21.

LAKATOS, Eva Maria \& MARCONI, Marina de Andrade. Metodologia do trabatho clentifico, 4, ed. Săo Paulo: Atlas, 1992.

MARTINS, Eliseu. Contabilidade de custos. 6. ed. São Paulo: Atlas, 1998.

O Papel da profissāo na regulaçăo dos mercados. Revista Brasileira de Contabiìidade. n. 80 , p. $64-69$, jul/set. 1992.

MILLS, P. A. Words and the study of accounting history. Accounting, Auditing and Accountability Journal, (janeiro 1990): 21-35.
MOONITZ, Maurice. The besic postulates of accounting. New York : AICPA, 1961.

MOST, Kenneth S. Accounting theory. Colombus: Grid, 1977.

POUND, G. D. A note on audit report readability. Accounting and Finance (Maio 1981): 45-55.

RIAHI-BELKAOUI, Ahmed. The linguistic shaping of accounting. Quorum Books, Westport, Connecticut: London.

SCHROEDER, Nicholas; GIBSON, Charles. Readability of management's discussion and analysis. Accounting Horizons - dezembro 1990: 78-87.

SILVA, Benedito G. da. Sistema de informaçălo contábil sab a b́tica da teoria da comunicação: um estudo com administradores na regiăo da Grande Săo Paulo. Dissertaçăo de mestrado apresentada à FEAMUSP Sẫo Paulo - 1995.

SMITH, James E. \& SMITH, Nora P. Readability: a measure of the performance of the communication function of financial reporting. Accounting Roviow (Julho 1971):352-361.

SMITH, M. \& TAFFLER, R. The chairman's statement and corporate financial performance. Accounting and Finance. $n .1$ ( 1992): $75-90$.

SPROUSE, RobertT. \& MOONITZ, Maurice. A tentative set of broad accounting principles for business enterprises. New York: AICPA, 1962.

VAINI, Luis Carlos. O auditor do futuro. Trabalho apresentado no XIV Congresso Brasileiro de Contabilidade. Salvador- outubro de 1992.

WORTHINGTON, J.S. Making financial statement footnotes more readable. C. A. Magazine (september 1977): p. $34-37$,

\section{Nota do autor:}

Agradeço ao Professor Doutor L. Nelson Carvalho (FEA) USP) pelos comentärios e sugestōes gentilmente realizados na minuta deste artigo. 